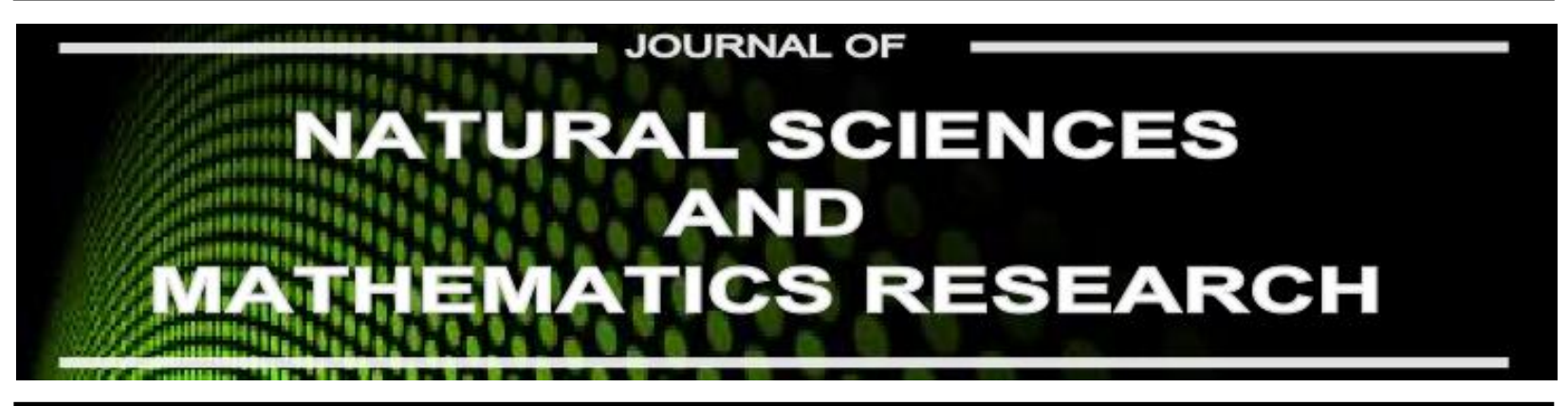

Available online at http://journal.walisongo.ac.id/index.php/jnsmr

\title{
Current State: The Development of Thin Film Solar Cells Based on Kesteritee Compound
}

\author{
Fianti1, Badrul Munir2, Kyoo Ho Kim3, and Mohammad Ikhlasul Amal4 \\ ${ }_{1}^{1}$ Department of Physics, Semarang State University, Central Java, Indonesia \\ ${ }^{2}$ Department of Metallurgical Engineering, University of Indonesia, Indonesia \\ 3Department of Materials Science and Engineering, Yeungnam University, 214-1 Daedong, Gyeongsan, \\ Gyeongbuk 712-749, Republic of Korea. \\ ${ }^{4}$ Indonesian Institut of Sciences (LIPI), South Tangerang, Indonesia.
}

\begin{abstract}
s
Corresponding author: muha137@lipi.go.id

Recived: 17 March 2016, Revised: 30 April 2016 Accepted: 10 June 2016.

Thin film solar cell experience fast development, especially for thin film solar cell $\mathrm{CdTe}$ and $\mathrm{Cu}(\mathrm{In}, \mathrm{Ga}) \mathrm{Se}_{2}$ (CIGS). However, the usage of rare element in the nature such as In, Te, and $\mathrm{Ga}$ and toxic such as $\mathrm{Cd}$ give limitation in the future development and production growth in big scale. Development of other alternative compound with maintain the profit of electronic and optic character which get from CIGS chalcopyrite compound will be explain. Compound of $\mathrm{Cu}_{2} \mathrm{ZnSnSe} 4$ (CZTSe) is downward compound from CIGS with substitute the In and Ga element with $\mathrm{Zn}$ and Sn. The compound kesterite structure can be modified with variation of chalcogen element to get wanted character in solar cell application. Efficiency record of photovoltaic devices conversion used this compound or downward reach 9.7\%.@2016 JNSMR UIN Walisongo. All rights reserved.
\end{abstract}

Key words: Thin Film; Solar Cell; Kesteritee Coumpond.

\section{Introduction}

Solar cell or it can be called photovoltaic, is a devices system that converse sun light to become electricity energy. In generally at 2010, installation of solar cell have gain number 18,2 gigawatt (GW) with statistical growth 139\% per year from the year before. This development is good if its compared with the global installation scope amounted 52 mega watt (MW) on year 2000 [1]. However, if it refer to the needed of electricity usage per year, solar cell only give contribution amounted $0,1 \%$. It is because the expense that needed for technology usage of solar cell is expensive if compared with technology that used conventional energy source based fossil (oil, coal, etc). for can compete with other technology of alternative energy, at least there are four rule and regulation that should be 
fulfill in solar cell development: i) high conversion efficiency, ii) long life devices system, iii)material availability, iv) cheap production cost for big scale.

In market scope of solar cell, solar cell based silicon is first generation development of photovoltaic technology, it is dominate in market segment amounted $80 \%$. the dominate of silicon solar cell is because by historical the development of silicon material in semiconductor and electronic application is long standing conducted, so that the usage in application of solar cell only become the diversification of silicon material application for silicon industries in proper place. Beside that, availability of silicon as basic material is over abundance and environment impact of silicon degradation is low. Until now, it is note down that efficiency of silicon solar cell is $25 \%$ for laboratory scale of submodule crystalline silicon [2] and 23\% for silicon of terrestrial module crystalline [3], both is development by UNSW. Solar cell of crystalline silicon need silicon wafer is thick as 250-300 $\mu \mathrm{m}$ for absorb light fraction by efficient. Besides that, crystal formation should be single complete because there is granule limit became active location to recombination center. This both condition caused high production cost of silicon solar cell so it is difficult to compete with other energy power source technology. Diversification of silicon usage for solar cell application such as multi-crystalline silicon, amorphous silicon, thin film silicon also developed but not gain success yet such as crystalline silicon. Deficiencies of solar cell based silicon is become a reason for the development of second solar cell that needed less material and easy process.

Second generation of photovoltaic technology is solar cell of thin film shows the increasing continue with market segment gain amounted 15\% in year 2010 from 6\% in year 2005 [1]. the definition of thin film material is more precisely conducted based on production process better than based on thickness border, that is material that manufactured with nucleation process and random growth from molecular/ionic/atomic species that reacted or condensation with complete on a substrate. In general, method for deposition material of thin film can be divide in two, that is vacuum method (thermal evaporation, sputtering, laser deposition, atomic layer deposition, etc) and non-vacuum (electro-deposition, sol-gel, spray pyrolisis, etc). The atomic process, nucleation, and random growth can be produced new and exotic characteristic of thin film material. This characteristics can controlled and reproduced through variation of deposition parameter.

Material that can be application as absorb layer or active layer on solar cell by ideal should have band gap value $\sim 1.5 \mathrm{eV}$, high optic absorption $\left(\sim 10^{5}\right)$, high quantum efficiency value, long distance diffusion, low recombination velocity, and it can formed good electronic junction. Optimum thickness from active layer of solar cell is reverse with optic absorption coefficient, so the material thickness can be reduction as far as the light absorption ability of material. In thin film application, the material thickness is needed more over 1-2 $\mu \mathrm{m}$, beside that the regulation of crystalline quality is more tolerant is because of the granule limit has less active character as recombination center. Some materials which has character as called above is: CdTe, GaAs, Cu2S, Cu2O, Zn3P2, and compound or descend combination such as chalcopyrite (I-III-VI). silicon material also develop with thin film approach with amorphous or crystalline.

However, at the moment the solar cell of thin film has limit because the technology development is not in proper place yet, included the intense of infrastructure development for production in big scale so it have the impact to high production cost. Beside that, factor of long time stability and usage of toxic material and expensive become challenge in development of thin film solar cell.

Beside the deficiencies from the first and second generation in solar cell, there is theoretical prediction about the probability to pass the limit of Shockley-Queisser (the efficiency amounted $31-41 \%$ for solar cell single band gap), it is produced third generation of solar cell. The third solar cell is 
involve the technology and material of nonconventional nano-structure such as multilayer/tandem cell, sensitive color cell (dyesensitized solar cell), organic cell, intermediate band gap cell, quantum dot, and hot-carriers cell. Because of the unripe development that compared with the two pioneer, the third generation of solar cell is not show the significant penetration. For example, efficiency record for DSSC is 10,4\% [4] and solar cell of organic polymer: 5,15\% [5]. For tandem cell $\mathrm{GaInP} / \mathrm{GaAs} / \mathrm{Ge}$ gain the efficiency record is $32 \%$, it is the higher among the technology of other solar cell, however the complex technology usage caused the technology can not cut down to big scale. It is also become general problem for third technology of solar cell. Figure 1 is illustrated the estimation of the cost that needed and conversion efficiency that produced for each generation [6]. Solar cell of crystalline silicon is difficult to understanding in gain the low production cost target, while the technology of thin film is believed has potential as alternative in short term time. This article is deeply discuss the development trend, opportunity and challenge of solar cell of thin film especially based on material of kesterite compound.

\section{Chalcopyrite Compound and The Downward}

Development of new material for semiconductor and electronic application can be done with the downward from the element of group IV with combination of element in related group, such as binary compound with sphalerite and chalcopyrite ternary structure. The compound of the downward multi element have new character that different with origin element/compound. The systematic of downward and element combination so its produced structure and different compound combination such as shown at Figure 2.

Sphalerite compound II-VI CdTe and the Chalcopyrite compound I-III-VI2 CuInS2 (CIS) is material that by history is previous and application for solar cell. At this time, efficiency record of solar cell based CdTe is $16,7 \%$ for laboratory scale (NERL, [7]) and $10,9 \%$ for terrestrial module of industry scale (BP Solarex, [8]). Market penetration for this material has increased, even in China had started development project of electricity generator of solar power based CdTe that biggest in the world with capacity of $2 \mathrm{GW}$ in 2010 with finishing schedule in 2019 [9]. For CIS material, the development is done a modification with substitute a part of indium atom with gallium atom, formed $\mathrm{Cu}(\mathrm{In}, \mathrm{Ga}) \mathrm{Se} 2$ (CIGSe) compound. Module of solar cell with active layer used $\mathrm{Cu}(\mathrm{In}, \mathrm{Ga}) \mathrm{Se} 2$ material had gain efficiency amounted 19,4\% for laboratory scale cell (NREL) [10] and 13,8\% for terrestrial module that develop by Miasole [11].

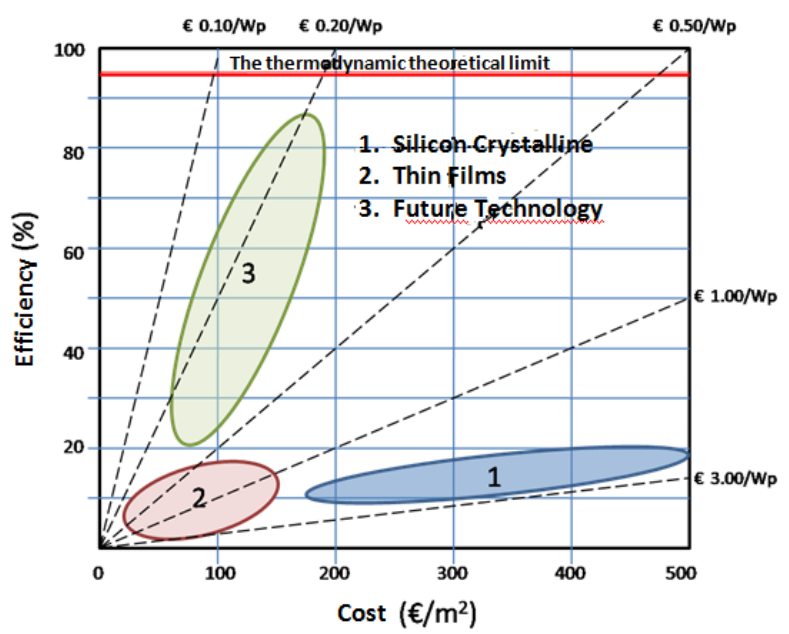

Pigure 1. Analysis of efficiency cost for solar cell of crystalline silicon, thin film, and third generation (adapted from ref [6]).

As stated before, compound of ternary of I-III-VI2 such as CIS can be modified with substitute the partial of group III element with a number of equivalent element of group II and IV become compound of quartener I-II-IV-VI2 CIGSe. Beside modified the metal element, alternative compound also can synthetic with changing the kalkogen element such as sulfur and selenium. So the combination of element and contents in this compound if its variation can produce different characters. For example, variation of indium and gallium ratio of CIGSe compound produce different electric and optic 
character. Such as substitute the entire or partial of selenium with sulfur can change the level of conductivity ribbon and valence so make possible to variate the band gap value from $\sim 1.1 \mathrm{eV}$ for $\mathrm{Cu}(\mathrm{In}, \mathrm{Ga}) \mathrm{Se} 2$, it is gain $\sim 1.5$

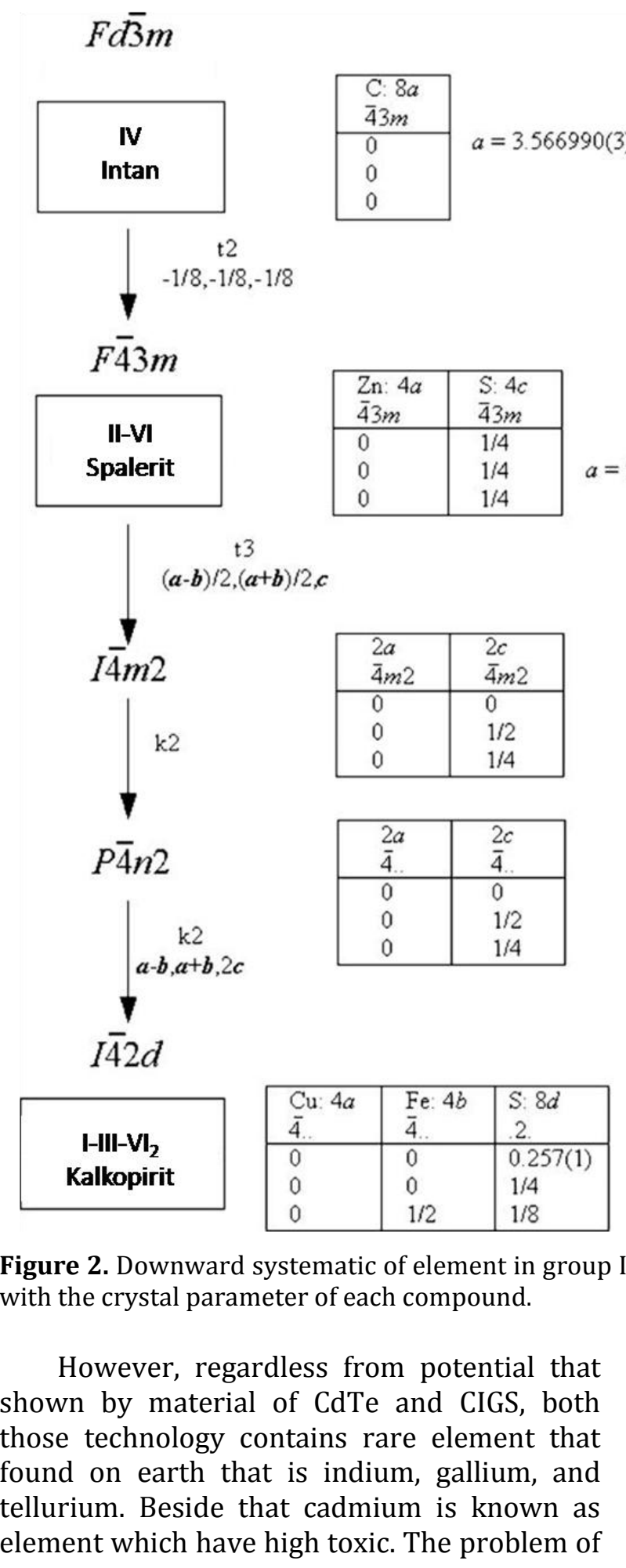

$\mathrm{eV}$ for $\mathrm{Cu}(\mathrm{In}, \mathrm{Ga}) \mathrm{S} 2$ (CIGS). The freedom in developing the wanted character in compound based chalcopyrite made it as research focus in many laboratory.

\section{$=5.415(9) \AA$}

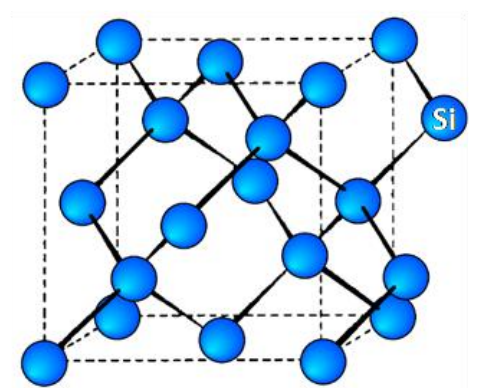

Intan Si

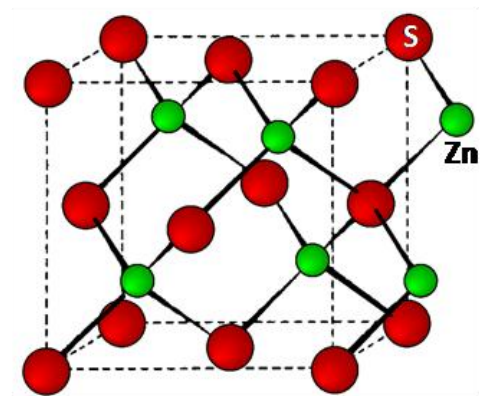

Spalerit ZnS

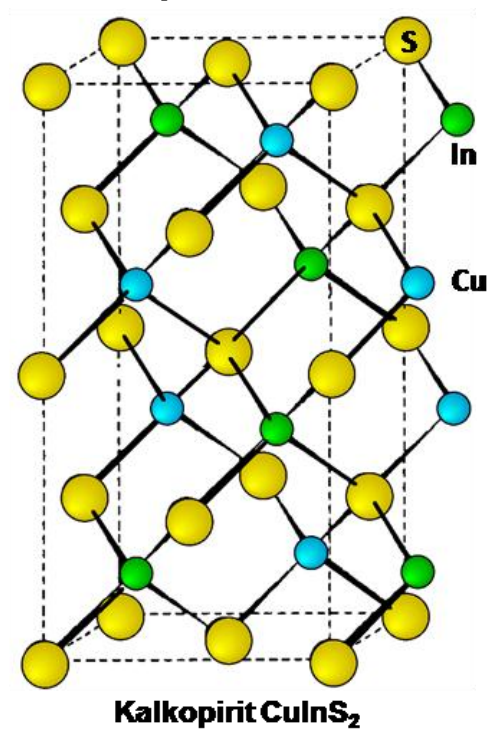

$a=5.2864(8) \AA$ $c=10.4102(8) \AA$ availability and environment, made the researcher started to find other alternative material that more cheap and used mineral element which available in the nature and environment friendly. One of alternative material for solar cell of thin layer is 
Cu2ZnSnSe4 (CZTSe),is downward compound from CIGS which gain by substitute the indium and gallium element with zinc and tin that more cheaper and environment friendly.

Even though, it is adopted the same crystal element, that is chalcopyrite, but because of the changing of atom position which substituted, so quartener compound have own crystal structure that is kesterite or stannite, where is the different is in the organization of element atom I in crystal sub kisi. The analysis result used neutron diffraction [12] had confirm that CZTSe have kesterite structure that stannite structure which supported by theoretic calculation [13]. In the same with CIGS, this compound can modified with changing kalkogen element to get different material characteristic, so it can be made three variation compound that is CZTSe, CZTS, or partial substitute produced CZTSSe.

This material fabrication can be done with various method such as explain before. One of the method that wide application is combination of vacuum deposition with selenization/sulfurization thermal reaction. Superiority of the method is stability and reproducible and easy to develop in big scale. Our laboratory develop deposition method with two steps that is production of metal precursors with sputtering target alloy $\mathrm{Cu}-\mathrm{Sn}$ $\mathrm{Zn}$ and selenization/sulfurization on temperature $400{ }^{\circ} \mathrm{C}$ or higher to produce single phase of CZTSSe. Picture 3 shows that micro structure of three compound that is CZTSe, CZTS, and CZTSSe which produced used this method. It is seen difference contents of $\mathrm{S} / \mathrm{Se}$ element, it give impact on microstructure visualization where is CZTSe has bigger granule than CZTS. Beside that diffraction pattern of X-ray for 112 area shows the difference of intensity and position $2 \theta$ as an effect of different ratio of S/Se. The band gap value of CZTSe is1.1, the band gap value of CZTSSe is 1.3, and the band gap value of CZTS is $1.54 \mathrm{eV}$ (ratio $\mathrm{S} / \mathrm{Se}=1$ ). The problem that usually found in compound fabrication is evaporation of $\mathrm{Zn}$ and $\mathrm{Sn}$ element that caused deviation by stoichiometry and produce secondary phase that is unwanted [14].

CZTSe had been researched have character which can be application for solar cell, Wibowo et.al, report that film of CZTSe with high absorption coefficient amounted $10^{4} \mathrm{~cm}^{-1}$, resistance amounted $1.482 \Omega \mathrm{cm}$ and carrier concentration amounted $10^{19} \mathrm{~cm}^{-}$ 3 [15]. In the first development of photovoltaic devices used this material in 1996, its reported the efficiency value amounted $0.66 \%$ for devices of solar cell glass structured /Mo/CZTS/CdS/ZnO:Al [16].The number is increase become $2,3 \%$ in the next year based on the development that conducted by Friedlmeier et al. [17]. For this time, the efficiency record is $6.8 \%$ for solar cell of CZTS [18], 3.2\% for solar cell of CZTSe [19], and $9.7 \% \%$ for solar cell of CZTSSe [20]. For the both devices mention before used technology of vacuum deposition while for solar cell of CZTSSe used process of chemical synthesis based solution. Beside that, presentation above also describe the development of solar cell used CZT(Se,S) material is slow development with increasing of efficiency record more than one decade, but for this time the development shows good potential so projection of market penetration is conducted more faster. Table 2 shows the devices development of solar cell used CZT(Se,S) material with different fabrication method.

\section{Devices of Solar Cell CZTSSe}

In this section, it will be detail discussed about devices of solar cell that produced higher efficiency value, with active layer of CZTSSe is made used solution method (hidrazin) which development by IBM T.J Watson Research Center on year 2010 [20]. Picture 4 shows the typical of diameter across of solar cell devices with structure of soda lime glass/Mo/CZTSSe/CdS/ZnO/ITO with contact grid of $\mathrm{Ni}-\mathrm{Al}$ and layer of $\mathrm{MgF} 2$ anti reflection. Total area of devices amounted $0.44 \mathrm{~cm} 2$ give efficiency amounted 9.7\%, Voc $=0.448 \mathrm{~V}$, $\mathrm{Jsc}=32.3 \mathrm{~mA} / \mathrm{cm} 2$, dan $\mathrm{FF}=67 \%(\mathrm{Voc}=$ open 
circuit voltage, Jsc $=$ short-circuit current density, FF = fill factor).

Evaluation from the result of devices characteristic found several thing that become deficiency and cause of the performed limited that is: first, good thin film of solar cell have contradiction between $\mathrm{Voc}$ and $\mathrm{Eg} / \mathrm{q}$ appropriate to $0.5 \mathrm{~V}$, where is $\mathrm{Eg}$ is band gap and $\mathrm{q}$ is electron capacity. While, this devices have $\mathrm{Eg} / \mathrm{q}$ value more than $0.6 \mathrm{~V}$. it is give indication of main recommendation
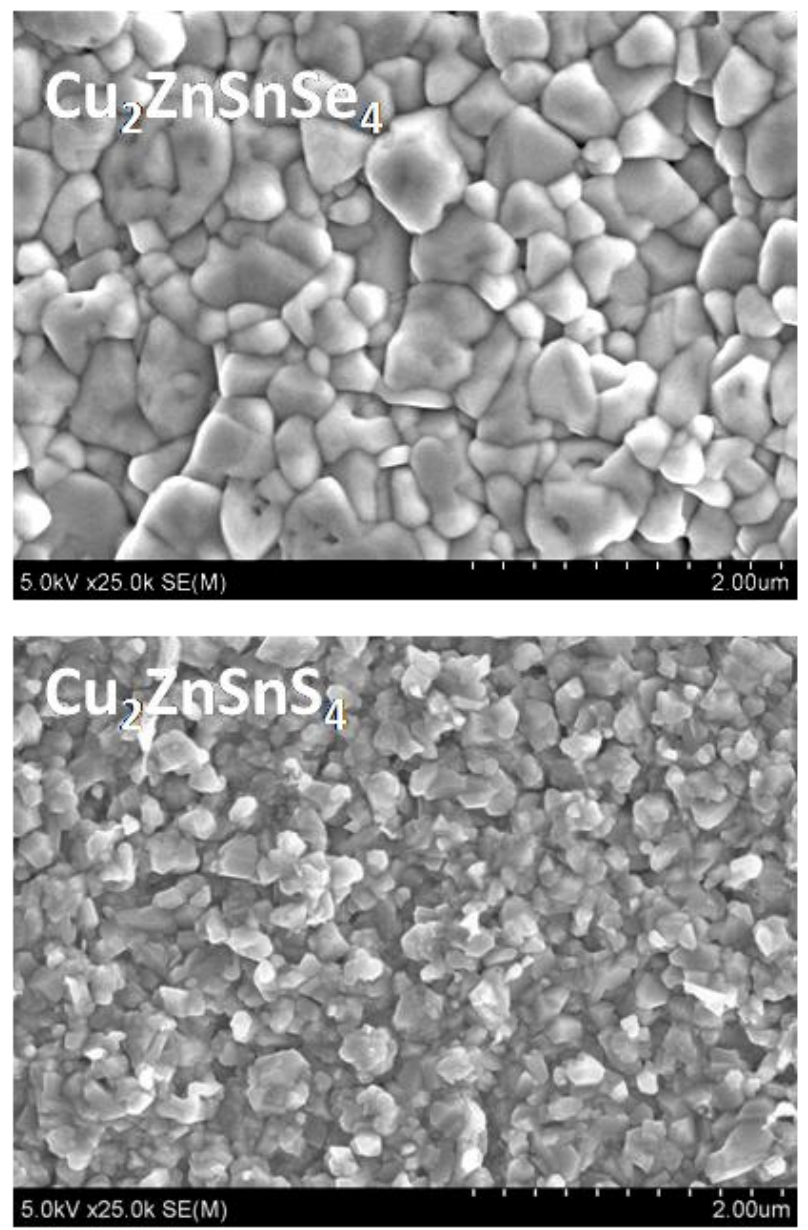

mechanism which dominated by interface recommendation. Second, FF value is lower its might be caused by the higher of obstruction as consequence of obstacle of back contact in interface area between Mo and CZTSSe so its push down the transportation of majority carrier (hole). Third, response of quantum efficiency for big wave long area of band gap limit is low, with short minority carrier life time more over $\sim 1.2 \mathrm{~ns}$.
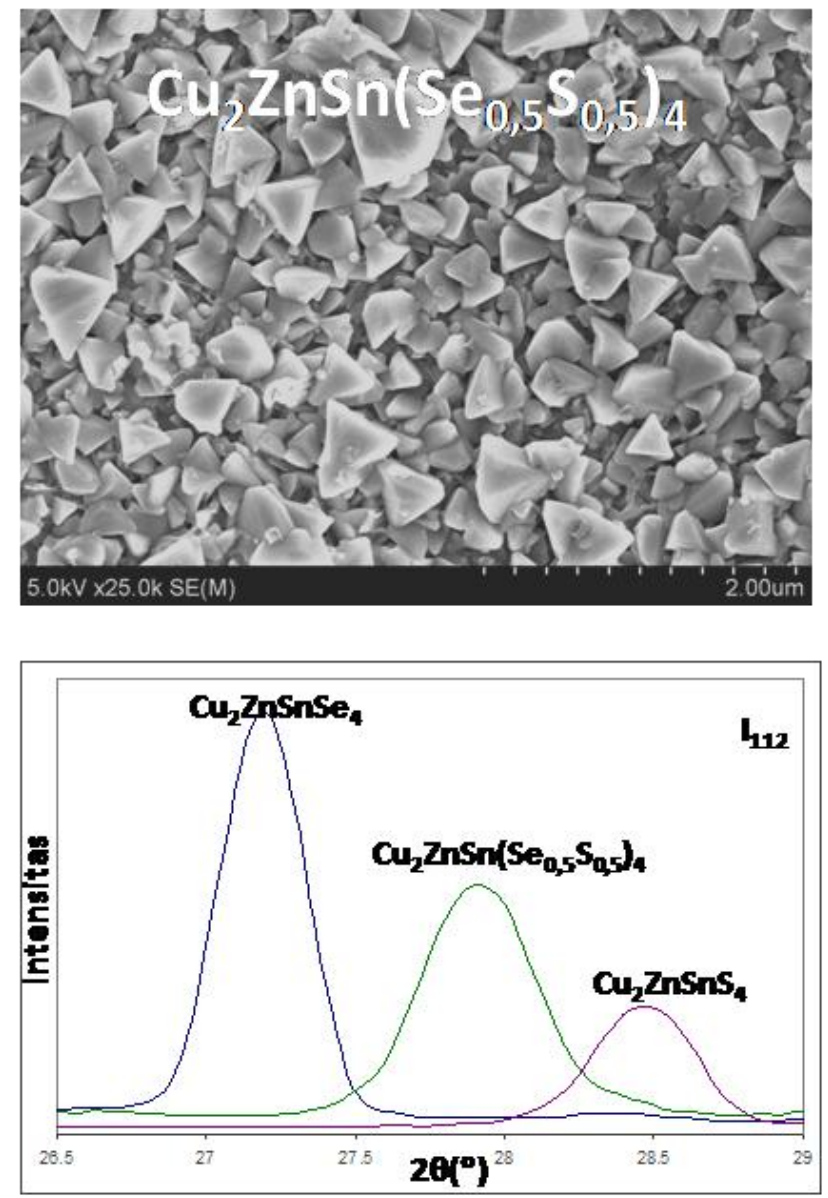

Figure 3. Micro-structure of CZTSe compound with kalkogen contents variation along with the patter of X-ray diffraction 
Table 2. Summary of devices efficiency of solar cell CZT(Se,S) with different fabrication method

\begin{tabular}{|c|c|c|c|c|}
\hline Year & Material & Fabrication method & Efficiency (\%) & Ref. \\
\hline 1997 & CZTS & Evaporation Electron beam + sulfurization & 0.66 & {$[16]$} \\
\hline 1997 & CZTSe & Evaporation multi-element & 0.6 & {$[17]$} \\
\hline 1997 & CZTS & Evaporation multi-element & 2.3 & {$[17]$} \\
\hline 2001 & CZTS & Evaporation multi-element & 2.62 & {$[21]$} \\
\hline 2003 & CZTS & Evaporasi element $+\mathrm{ZnS}+$ control doping $\mathrm{Na}$ & 5.45 & {$[22]$} \\
\hline 2007 & CZTS & RF co-sputtering Cu-ZnS-SnS & 5.74 & {$[23]$} \\
\hline 2008 & CZTS & RF co-sputtering $\mathrm{Cu}-\mathrm{ZnS}-\mathrm{SnS}+$ annealing + etching & 6.77 & [18] \\
\hline 2008 & CZTS & Deposition pulsed-laser & 0.64 & {$[24]$} \\
\hline 2008 & CZTS & Elektrodeposition $\mathrm{Zn}-\mathrm{Sn}-\mathrm{Cu}+$ sulfurization & 0.8 & {$[25]$} \\
\hline 2009 & CZTSe & Sputtering multi layers + selenization & 3.2 & {$[26]$} \\
\hline 2009 & CZTS & Evaporation $\mathrm{Cu}-\mathrm{Sn}-\mathrm{S}-\mathrm{ZnS}$ & 1.1 & {$[27]$} \\
\hline 2009 & CZTS & Elektrodeposition element + sulfurization & 0.98 & {$[28]$} \\
\hline 2009 & CZTS & Co-elektrodeposition & 3.16 & {$[29]$} \\
\hline 2009 & CZTS & Co-elektrodeposition + etching + annealing & 3.4 & {$[30]$} \\
\hline 2009 & CZTS & Sol-gel + spin coating & 1.01 & {$[31]$} \\
\hline 2009 & CZTS & Sol-gel + spin coating & 1.61 & {$[32]$} \\
\hline 2009 & CZTS & Deposition nanoparticle & 0.23 & {$[33]$} \\
\hline 2009 & CZTS & Deposition nanoparticle + annealing & 0.74 & {$[34]$} \\
\hline 2009 & CZTSe & Single grain layer & 2.16 & {$[35]$} \\
\hline 2010 & CZTS & Evaporation Cu-Sn-S-ZnS + etching & 4.1 & {$[36]$} \\
\hline 2010 & CZTS & Evaporation Cu-Zn-Sn-S + annealing & 6.8 & {$[37]$} \\
\hline 2010 & CZTS & $\begin{array}{l}\text { Elektrodeposition } \mathrm{Zn}-\mathrm{Cu}-\mathrm{Sn}-\mathrm{Cu}+\text { sulfurization + } \\
\text { etching }\end{array}$ & 3.2 & {$[38]$} \\
\hline 2010 & CZTS & Ball-milling + screen printing + hot pressing & 0.49 & {$[39]$} \\
\hline 2011 & CZTSSe & Chemical reaction with hydrazine solvent & 9.7 & {$[20]$} \\
\hline
\end{tabular}

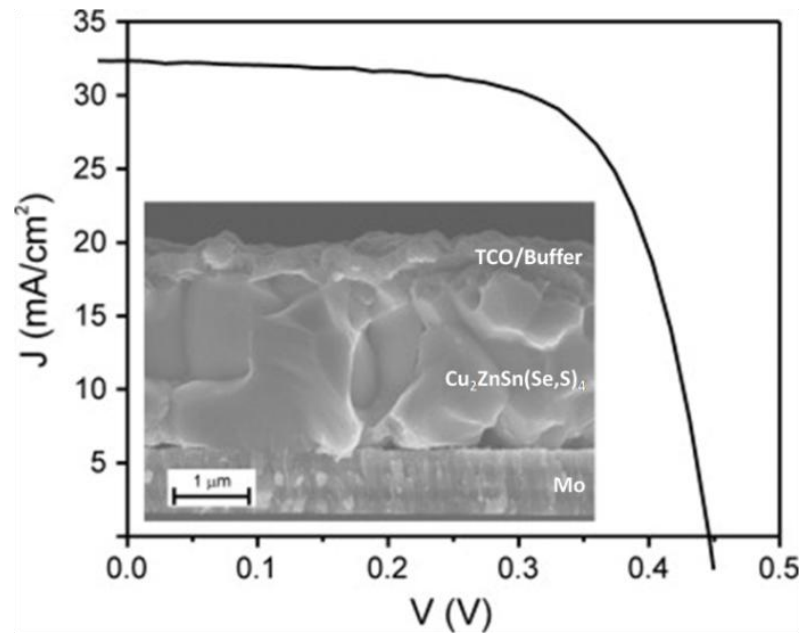

Figure 4. The curve of $\mathrm{J}-\mathrm{V}$ light under simulation of AM 1.5 light for devices solar cell of soda lime/Mo/CZTSSe/CdS/ZnO/ITO (insert) with efficiency amounted $9.7 \%$, Voc $=0.448 \mathrm{~V}$, Jsc $=32.3$ $\mathrm{mA} / \mathrm{cm}^{2}$, and $\mathrm{FF}=67 \%[20]$.

\section{Conclusion and Future Development}

Solar cell of thin film especially with active compound of CZT(S,Se) have create an opportunity to development of environment friendly solar cell and element utilized that abundant available in nature with good electronic character. Development more over last two year have been gain devices efficiency almost $10 \%$, it is appropriate with level of solar cell thin layer that have been develop before such as CdTe and CIGS. With the various method of fabrication that proved to synthesis the material, it is give an opportunity to develop and increase the wide quality because the character of the material is related with fabrication method, the general problem in 
material synthesis is easiest of element evaporation such as $\mathrm{Sn}$ and $\mathrm{Zn}$ and formation of seconder phase that can limit the solar cell perform.

The other thing that should be done is doing research of phase change in formation of CZT(S,Se) compound, it is needed detail understanding of interface character, optimum layer in devices interface, knowledge of natural defects character in active layer, and test of long life stability towards devices of solar cell CZT(S,Se). The beginning result that explanation before is show the future chances of solar cell CZT(S,Se). It is expected that the intense research and development in the future can realization the cheap and save solar cell for environment.

\section{Acknowledgment}

The author wish to thank to Department of Physics, Semarang State University, Department of Metallurgical Engineering, University of Indonesia, Department of Materials Science and Engineering, Yeungnam University, Indonesian Institut of Sciences (LIPI), South Tangerang, Indonesia for support in this research.

\section{References}

[1] Solarbuzz Reports World Solar Photovoltaic Market Grew to 18.2 Gigawatts in 2010, Up $\quad 139 \% \quad \mathrm{Y} / \mathrm{Y}$, http://www.prweb.com, 2011.

[2] J. Zhao, A. Wang, M.A. Green, F. Ferrazza. Novel 19.8\% efficient 'honeycomb' textured multicrystalline and $24.4 \%$ monocrystalline silicon solar cells. Applied Physics Letters 73, 1998, pp.19911993.

[3] J.Zhao, A. Wang, F. Yun, G.Zhang, D.M. Roche, S.R. Wenham, M.A. Green. 20,000 PERL silicon cells for the ' 1996 World Solar Challenge' solar car race. Progress in Photovoltaics: Research and Applications. 5, pp. 269-276, 1997.

[4] M. Morooka, K. Noda. Development of dye-sensitized solar cells and next gen- eration energy devicess, $88^{\text {th }}$ Spring Meeting of The Chemical Society of Japan, Tokyo, 26 March 2008.

[5] http://www.konarka.com (2011)

[6] M.A. Green, J. Zhao, A. Wang and S.R. Wenhan, Progress and outlook for high efficiency crystalline silicon solar cells, Solar Energy Materials and Solar Cells 65, pp. 9-16, 2001.

[7] X. Wu, J.C. Keane, R.G. Dhere, C. DeHart, A. Duda, T.A. Gessert, S. Asher, D.H. Levi, P. Sheldon, 16.5\%- efficient CdS/CdTe polycrystalline thin-film solar cell, Proceedings of 17th European Photovoltaic Solar Energy Conference, Munich, 22-26, pp. 995-1000, October 2001.

[8] D. Cunningham, K. Davies, L. Grammond, E. Mopas, N. O'Connor, M. Rubcich, M. Sadeghi, D. Skinner, T. Trumbly. Large area ApolloTM module performance and reliability, Conference Record, 28th IEEE Photovoltaic Specialists Conference, Alaska, September, pp.13-18, 2000.

[9] I. Repins, M. Contreras,Y. Romero, Y. Yan, W. Metzger, J.Li, S. Johnston, B. Egaas, C. DeHart, J. Scharf, B.E McCandless, R. Noufi. Characterization of 19.9\%efficienct CIGS absorbers, $33_{\text {th }}$ IEEE Photovoltaics Specialists Conference Record, 2008.

[10] http://www.miasole.com, 2011.

[11] S. Chorr, The crystal structure of kesteritee type compounds: A neutron and X-ray diffraction study, Solar Energy Materials \& Solar Cells, 95, pp.14821488, 2011.

[12] T. Maeda, S. Nakamura, T. Wada, Phase stability and electronic strucutre of Infree photovoltaic semiconductors, $\mathrm{Cu} 2 \mathrm{ZnSnSe} 4$ and $\mathrm{Cu} 2 \mathrm{ZnSnS4}$ by first principles calculation, Mater. Res. Soc. Symp. Proc. 1165, pp. M04-03, 2009.

[13] I. Amal, K. Kyoo Ho, Formation of CZTSeS by two step fabrication, in submission, 2011.

[14] R.A. Wibowo, W.S. Kim, E.S. Lee, B. Munir, K.H. Kim, Single Step preparation of quartenary $\mathrm{Cu} 2 \mathrm{ZnSnSe} 4$ thin films by RF magnetron sputtering from binary 
chalcogenide targets, Journal of Physics and Chemistry of Solids 68, pp.19081913, 2007.

[15] H. Katagiri, N. Sasaguchi, S. Hando, S. Hoshino, J. Ohashi and T. Yokota, Preparation and evaluation of $\mathrm{Cu} 2 \mathrm{ZnSnS} 4$ thin films by sulfurization of E-B evaporated precursors, Sol. Energy Mater. Sol. Cells 49, pp. 407-414, 1997.

[16] Th.M. Friedlmeier, N. Wieser, Th. Walter, H. Dittrich, H.-W. Schock, Heterojunctions based on $\mathrm{Cu} 2 \mathrm{ZnSnS4}$ and $\mathrm{Cu} 2 \mathrm{ZnSnSe} 4$ thin films, in: Proceedings of the ${ }^{14}$ th European Photovoltaic Solar Energy Conference, pp. 1242-1245, 1997.

[17] H. Katagiri, K. Jimbo, S. Yamada, T. Kamimura, W.S. Maw, T. Fukano, T. Ito and T. Motohiro, Enhanced conversion efficiencies of Cu2ZnSnS4-based thin film solar cells by using preferential etching technique, Appl. Phys. Express 1, pp. 41201, 2008.

[18] G. Zoppi, I. Forbes, R.W. Miles, P.J. Dale, J.J. Scragg and L.M. Peter, Cu2ZnSnSe4 thin film solar cells produced by selenisation of magnetron sputtered precursors, Prog. Photovolt:: Res. Appl. 17, pp. 315-319, 2009.

[19] D.B. Mitzi, O. Gunawan, T. K. Todorov, K. Wang, S. Guha, The path towards a highperformance solution-processed kesteritee solar cell, Sol. Energy Mater. Sol. Cells. 95, pp. 1421-1436, 2011.

[20] H. Katagiri, K. Saitoh, T. Washio, H. Shinohara, T. Kurumadani and S. Miyajima, Development of thin film solar cell based on Cu2ZnSnS4 thin films, Sol. Energy Mater. Sol. Cells 65, pp. 141-148, 2001.

[21] H. Katagiri, K. Jimbo, K. Monya, K. Tsuchida, Solar cell without environmental pollution by using CZTS thin film, in: Proceedings of the World Conference on Photvoltaics Energy Conversion III, pp. 2874-2879, 2003.

[22] K. Jimbo, R. Kimura, T. Kamimura, S. Yamada, W.S. Maw, H. Araki, K. Oishi and H. Katagiri, Cu2ZnSnS4-type thin film so- lar cells using abundant materials, Thin Solid Films 515, pp. 5997-5999, 2007.

[23] K. Moriya, K. Tanaka and H. Uchiki, Cu2ZnSnS4 thin films annealed in H2S atmosphere for solar cell absorber prepared by pulsed laser deposition, Jpn. J. Appl. Phys. 47, pp. 602-604, 2008.

[24] J.J. Scragg, P.J. Dale, L.M. Peter, G. Zoppi and I. Forbes, New routes to sustainable photovoltaics: evaluation of $\mathrm{Cu} 2 \mathrm{ZnSnS} 4$ as an alternative absorber material, Phys. Status Solidi B 245, pp. 1772-1778, 2008.

[25] G. Zoppi, I. Forbes, R.W. Miles, P.J. Dale, J.J. Scragg and L.M. Peter, Cu2ZnSnSe4 thin film solar cells produced by selenisation of magnetron sputtered precursors, Prog. Photovolt: Res. Appl. 17, pp. 315-319, 2009.

[26] A. Weber, H. Krauth, S. Perlt, B. Schubert, I. Kötschau, S. Schorr and H.W. Schock, Multi-stage evaporation of $\mathrm{Cu} 2 \mathrm{ZnSnS4}$ thin films, Thin Solid Films 517, pp. 2524-2526, 2009.

[27] H. Araki, Y. Kubo, A. Mikaduki, K. Jimbo, W.S. Maw, H. Katagiri, M. Yamazaki, K. Oishi and A. Takeuchi, Preparation of $\mathrm{Cu} 2 \mathrm{ZnSnS4}$ thin films by sulfurizing electroplated precursors, Sol. Energy Mater. Sol. Cells 93, pp. 996-999, 2009.

[28] H. Araki, Y. Kubo, K. Jimbo, W.S. Maw, H. Katagiri, M. Yamazaki, K. Oishi and A. Takeuchi, Preparation of Cu2ZnSnS4 thin films by sulfurization of coelectroplated $\mathrm{Cu}-\mathrm{Zn}-\mathrm{Sn}$ precursors, Phys. Status Solidi C 6, pp. 1266-1268, 2009.

[29] A. Ennaoui, M. Lux-Steiner, A. Weber, D. Abou-Ras, I. Kötschau, H.-W. Schock, R. Schurr, A. Hölzing, S. Jost, R. Hock, T. Voß, J. Schulze and A. Kirbs, Cu2ZnSnS4 thin film solar cells from electroplated precursors: novel low-cost perspective, Thin Solid Films 517, pp. 2511-2514, 2009.

[30] K. Tanaka, M. Oonuki, N. Moritake and H. Uchiki, Cu2ZnSnS4 thin film solar cells prepared by non-vacuum processing, Sol. 
Energy Mater. Sol. Cells 93, pp. 583-587, 2009.

[31] N. Moritake, Y. Fukui, M. Oonuki, K. Tanaka and H. Uchiki, Preparation of Cu2ZnSnS4 thin film solar cells under non-vacuum condition, Phys. Status Solidi C 6, pp. 1233-1236, 2009.

[32] C. Steinhagen, M.G. Panthani, V. Akhavan, B. Goodfellow, B. Koo and B.A. Korgel, Synthesis of $\mathrm{Cu} 2 \mathrm{ZnSnS} 4$ nanocrystals for use in low-cost photovoltaics, J. Am. Chem. Soc. 131, pp. 12554-12555, 2009.

[33] Q. Guo, H.W. Hillhouse and R. Agrawal, Synthesis of $\mathrm{Cu} 2 \mathrm{ZnSnS4}$ nanocrystal ink and its use for solar cells, J. Am. Chem. Soc. 131, pp. 11672-11673, 2009.

[34] K. Timmo, M. Altosaar, J. Raudoja, K. Muska, M. Pilvet, M. Kauk, T. Varema, M. Danilson, O. Volobujeva and E. Mellikov, Sulfur-containing $\quad \mathrm{Cu} 2 \mathrm{ZnSnSe} 4$ monograin powders for solar cells, Sol. Energy Mater. Sol. Cells. 94, pp. 18891892, 2010.
[35] B.-A. Schubert, B. Marsen, S. Cinque, T. Unold, R. Klenk, S. Schorr, H.-W. Schock, Cu2ZnSnS4 thin film solar cells by fast coevaporation, Prog. Photovolt:: Res. Appl. 2010.

[36] K. Wang, O. Gunawan, T. Todorov, B. Shin, S.J. Chey, N.A. Bojarczuk, D. Mitzi and S. Guha, Thermally evaporated Cu2ZnSnS4 solar cells, Appl. Phys. Lett. 97, pp. 143508 (3 pp), 2010.

[37] J.J. Scragg, D.M. Berg and P.J. Dale, A $3.2 \%$ efficient kesteritee devices from electrodeposited stacked elemental layers, J. Electroanal. Chem. 646, pp. 52-59, 2010.

[38] Z. Zhou, Y. Wang, D. Xu and Y. Zhang, Fabrication of $\mathrm{Cu} 2 \mathrm{ZnSnS4}$ screen printed layers for solar cells, Sol. Energy Mater. Sol. Cells 94, pp. 2042-2045, 2010. 